\title{
Drowning of algal mounds: records from the Upper Carboniferous Lower Pseudoschwagerina Limestone, Carnic Alps, Austria
}

\author{
Elias Samankassou * \\ Institut für Paläontologie, Universität Erlangen-Nürnberg, Loewenichstraße 28, 91054 Erlangen, Germany \\ Received 21 August 1998; accepted 19 March 1999
}

\begin{abstract}
Anthracoporella algal mounds, up to $22 \mathrm{~m}$ thick, occur within the cyclic sequences of the Lower Pseudoschwagerina Limestone (uppermost Carboniferous), Carnic Alps (Austria). Their depositional environment lay between the wave base and the base of the photic zone. The algal mounds are overlain by dark, well-bedded, cherty wackestones and packstones. The cherty limestones contain cephalopods, thick-shelled brachiopods, and sponge spicules and lack Anthracoporella in growth position. They are typical deeper-water sediments, deposited below the photic zone. This sequence records drowning episodes; the shallow-water algal mounds were drowned by relative rise of sea level as sea-bottom production shut down below the photic zone. The sedimentological and paleontological evidence of drowning are supported by geochemical data of two measured sections. The mean sulfur content of the well-oxygenated algal limestones is $0.02 \%$ for both sections; the TOC values are $0.17 \%$ for the section AI and $0.10 \%$ for the section AR. The S contents of the cherty limestones are approximately twice as high with values of 0.48 and $0.05 \%$ for the respective sections. TOC values of the cherty limestones are also significantly higher, with 0.30 and $0.51 \%$ contents for the respective sections. The cherty limestones document the termination of the mounds and the demise of reef-building algae in each cycle. This interval is therefore termed 'shroud facies'. The rapid sea-level rise reported is a further proof for high-magnitude sea-level fluctuations in intervals of glacio-eustasy. The documented drowning mode is novel through the definable interval of drowning, the repeated events during a short time interval, the full record of pre-, syn-, and post-drowning deposits, and the unequivocal attribution to glacio-eustatic sea-level rise. This mode seems to be characteristic of an icehouse period and clearly differs from the drowning mode in greenhouse periods which is often gradual, lacks an unequivocal cause, and is often preceded by subaerial exposure.
\end{abstract}

Keywords: drowning; shroud facies; glacio-eustasy; cyclothems; sea level; Upper Carboniferous; Carnic Alps; Austria

\section{Introduction}

Over the last decades, the drowning of carbonate platforms and reefs has received a lot of attention in the literature (Bernoulli and Jenkyns,

\footnotetext{
* Tel.: +49 9131 8524849; Fax: +49 9131 8522690; E-mail: samelias@pal.uni-erlangen.de
}

1974; Matthews et al., 1974; Poty, 1980; Kendall and Schlager, 1981; Schlager, 1981, 1989; Hurst et al., 1985; Schlager and Camber, 1986; Dominguez et al., 1988; Bosellini, 1989; Meyer, 1989; Bice and Stewart, 1990; Erlich et al., 1990; Lavoie, 1992; Santantonio, 1994; Blanchon and Shaw, 1995; Steinhauff and Walker, 1995; Szulczewski et al., 1996; Enos et al., 1998; cf. overview of fossil examples 
in table 1 of Schlager, 1981 and a recent review by Schlager, 1998). Cretaceous platforms have received particular scrutiny (Grötsch and Flügel, 1992; cf. papers in Simo et al., 1993; ODP Sites 875 and 876, papers by Camoin et al., 1995 and Enos et al., 1995; Wilson et al., 1998). Further examples of drowning are documented from the Quaternary, unequivocally related to high-frequency and high-magnitude sealevel changes typical of this glacial interval (e.g. Blanchon and Shaw, 1995).

Due to the wide extent of platforms (up to many $\mathrm{km}$ ), the diversity of factors causing drowning, and/ or slow rates of sea-level fluctuations, it is generally difficult to identify the precise drowning episode (Schlager, 1981, 1999; Erlich et al., 1990). Particularly, the gradual transition from shallow- to deeper-water facies, and subaerial exposure of some platforms prior to their final drowning (Schlager, 1989; Erlich et al., 1990; Camoin et al., 1995) often obscures or masks drowning episodes. These effects seem pronounced in greenhouse periods.

Upper Paleozoic cyclic sediments, recognized worldwide, have been deposited during high-frequency sea-level oscillations. They are characterized by parallel changes in facies and biotic composition (cf. examples from Midcontinent in Heckel, 1994; from the Canadian Arctic Archipelago in Beauchamp et al., 1989; from the Carnic Alps in Samankassou, 1997a,b). Such cycles offer the opportunity to analyse drowning events, their implications, and to approximate their timing. This paper documents the detailed reconstruction of the origin, depositional environment, and termination of Anthracoporella algal mounds within the Lower Pseudoschwagerina Limestones cyclothems. There, lithofacies, paleontology, and geochemistry record drowning of the mounds.

This novel mode of drowning is characterized by a rapid sea-level rise, a definable interval of drowning lacking a prior exposure surface, a full record of the pre-, syn-, and post-drowning facies, and repeated drowning events during a short time interval.

\section{Geological setting}

Basins formed by Variscan orogenic movements (late Namur to middle Westphalian) in the Car- nic Alps on the present Austrian-Italian border (Fig. 1), were filled with prodeltaic and shallowmarine sediments during the middle Carboniferous to Early Permian (Venturini, 1990). These sediments include the Upper Carboniferous to Lower Permian Auernig Group, the Rattendorf Group, and the Trogkofel Group (Fig. 2). The Auernig Group is composed of cyclic deposits (Auernig Rythmus sensu Kahler, 1955) with quartz-rich conglomerates, cross-bedded sandstones, bioturbated siltstones with trace and plant fossils, gray shales, and bedded and mounded limestones (cf. Krainer, 1992). The Rattendorf Group is subdivided into the Lower Pseudoschwagerina Limestone, the Grenzland Formation, and the Upper Pseudoschwagerina Limestone. The Auernig and Lower Pseudoschwagerina Limestone have comparable cyclic deposits, but the four cycles of the Lower Pseudoschwagerina Limestone contain more carbonate (Homann, 1969; Samankassou, 1997a). The modal Lower Pseudoschwagerina Limestone cycle, in ascending order, includes (a) finegrained marine sandstones, (b) bedded limestones, (c) massive algal limestones, (d) cherty limestones, and (e) bedded bioclastic limestones. The Trogkofel Group is composed mainly of massive reef carbonates (Flügel, 1980, 1981).

\section{Facies analysis: sedimentological and paleontological evidence of drowning}

\subsection{Mound intervals}

The mound intervals include two subfacies: (1) massive limestone, incorporating mounds up to 22 $\mathrm{m}$ thick composed of algal boundstone (Samankassou, 1998), and (2) bedded skeletal packstones of the intermound subfacies that become indistinctly bedded towards the mound core. The mound subfacies is characterized by an abundance of the dasycladalean alga Anthracoporella spectabilis Pia, 1920. The large thalli (10 $\mathrm{mm}$ and more) are mostly unbroken and in growth position, producing numerous shelter pores. These branched algae built a delicate framework, which was partially bound by Tubiphytes (Fig. 3; Samankassou, 1998). These dasyclads make up $90 \%$ of the total biota. The remaining $10 \%$ includes Epimastopora (one other dasyclad), fusulin- 


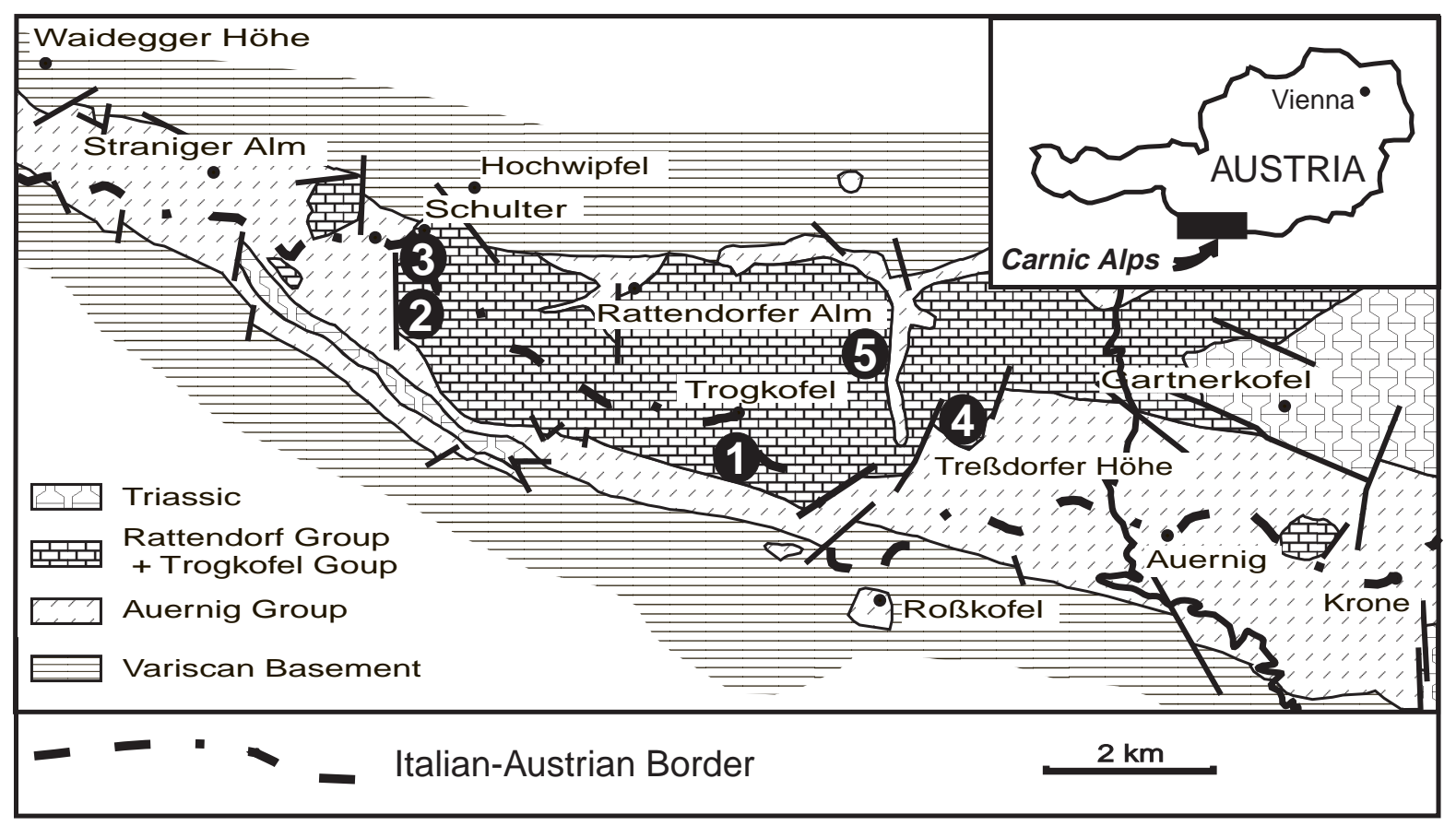

Fig. 1. Location of the Carnic Alps. Numbers 1-5 indicate study sites.

\begin{tabular}{|c|c|c|c|}
\hline \multirow{3}{*}{$\begin{array}{l}\text { Lower } \\
\text { Permian }\end{array}$} & Artinskian & $\begin{array}{l}\text { Trogkofel } \\
\text { Group }\end{array}$ & \\
\hline & Sakmarian & \multirow{3}{*}{$\begin{array}{l}\text { Rattendorf } \\
\text { Group }\end{array}$} & $\begin{array}{l}\text { Upper Pseudoschwagerina } \\
\text { Limestone }\end{array}$ \\
\hline & Asselian & & $\begin{array}{l}\text { Grenzland } \\
\text { Formation }\end{array}$ \\
\hline \multirow{3}{*}{$\begin{array}{c}\text { Upper } \\
\text { Carboniferous }\end{array}$} & \multirow[t]{2}{*}{ Gzhelian } & & $\begin{array}{c}\text { Lower Pseudoschwagerina } \\
\text { Limestone }\end{array}$ \\
\hline & & \multirow{2}{*}{$\begin{array}{l}\text { Auernig } \\
\text { Group }\end{array}$} & \\
\hline & Kasimovian & & \\
\hline
\end{tabular}

Fig. 2. Stratigraphy of the Carnic Alps showing the position of the Lower Pseudoschwagerina Limestone (dashed).

ids, and small foraminifers (Tuberitina, Endothyra, Tetrataxis, Calcitornella) (Fig. 3). The relative biodiversity is very low (Samankassou, 1997a). The space between the plants is filled by lime mud, with small foraminifers and other organisms, peloids, and early marine cement (Samankassou, 1998). The abundance of peloids give the matrix an inhomogeneous texture. The peloids are similar to those described by
Marshall (1983), Macintyre (1985), Chafetz (1986), Reid (1987), Guo and Riding (1992) and are interpreted as in-situ precipitates rather than infilling sediment. The well-preserved, delicate algal thalli, the unbroken branches (lower left of Fig. 3), the unwinnowed matrix with micritic cement and peloids, the abundance of Tubiphytes suggest deposition below wave base. The abundance of Anthracoporella 


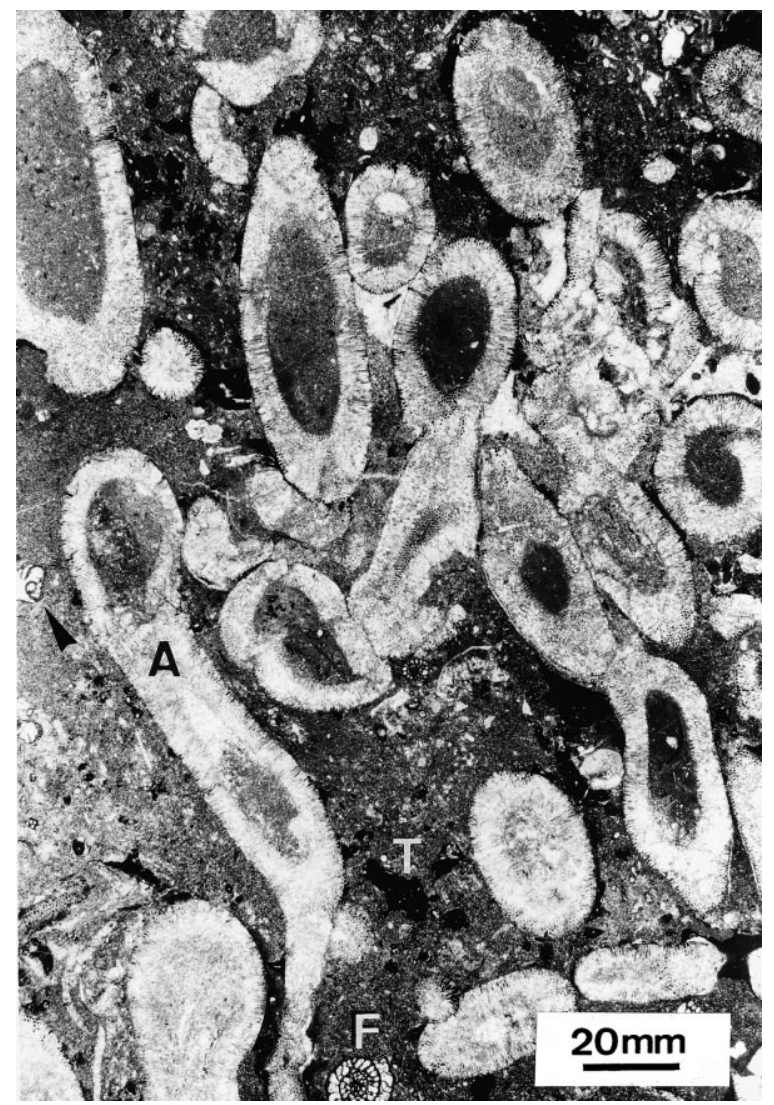

Fig. 3. Anthracoporella boundstone characteristic of the mound facies. The dasycladalean algae Anthracoporella Pia 1920 built a delicate framework (Samankassou, 1998). Small foraminifers (arrows), fusulinids $(F)$, and Tubiphytes $(T)$ occur within the cavities between algal thalli. Note the in-situ, intact, and several-mm-large thalli of Anthracoporella.

in growth position indicates deposition within the photic zone.

The intermound strata are approximately one third as thick as the mounds. The intermound subfacies, mostly composed of skeletal packstones, is biotically more diverse than the mound facies. Foraminifera are the dominant allochem. Anthracoporella in growth position and related fabrics are lacking; evidently algal growth, binding by Tubiphytes, rapid marine cementation, and the accumulation of lime mud in framework cavities were limited to the mound core (Samankassou, 1998). The intermound areas, which were slightly deeper than the mound facies, also lay below wave base. The elevated mounds channelized bottom currents in the lower relief intermound areas and led to accumulation of bioclasts (Kraft, 1993). These higher-energy intermound areas are characterized by packstones. The scarcity of Anthracoporella (less than $10 \%$ of the biota) indicates that either these limestones were deposited largely below the photic zone or the current regime restricted algal growth. The latter seems likely because a deeper-water biota characteristic of the lithologically distinct overlying cherty limestones is also lacking.

\subsection{Cherty limestones}

The limestones overlying the mounds are darkcolored, even-bedded, finely laminated, partly dolomitized, and contain chert nodules. They cover the mounds as well as adjacent intermound strata, without reworked or lag deposits, and are composed mainly of bioclastic wackestones and packstones and of spiculitic wackestones (Fig. 4). Nautiloids (Fig. 5), thick-shelled brachiopods, sponges, sponge spicules, and trilobites are the most common biota within these cherty limestones. Benthic biota is very sparse $(<5 \%)$. The dark micritic matrix surrounding the bioclasts is homogeneous. Anthracoporella spectabilis in growth position observed in the underlying mound facies is completely missing. No early cements occur in this facies, which can be characteristic of deeper-water environments. They can be clearly delineated from the mound interval (Fig. 6). This environment evidently lay below the photic zone as indicated by the abundance of sponge spicules along with the inhibited dasycladalean algal (or any other photosynthetic organisms) growth, the paucity of the benthic biota, and greater abundance of mud, in contrast to the underlying lithologies.

Facies and biotic composition indicate a marked sea-level rise: algal mounds were developed within the photic zone, whereas the overlying cherty limestones were deposited below the photic zone. The rising relative sea level outpaced algal growth and carbonate production shut down as the sea floor passed below the photic zone. The fact that the cherty limestones can be delineated from mound limestones as well as from the slightly deeper intermound lime- 


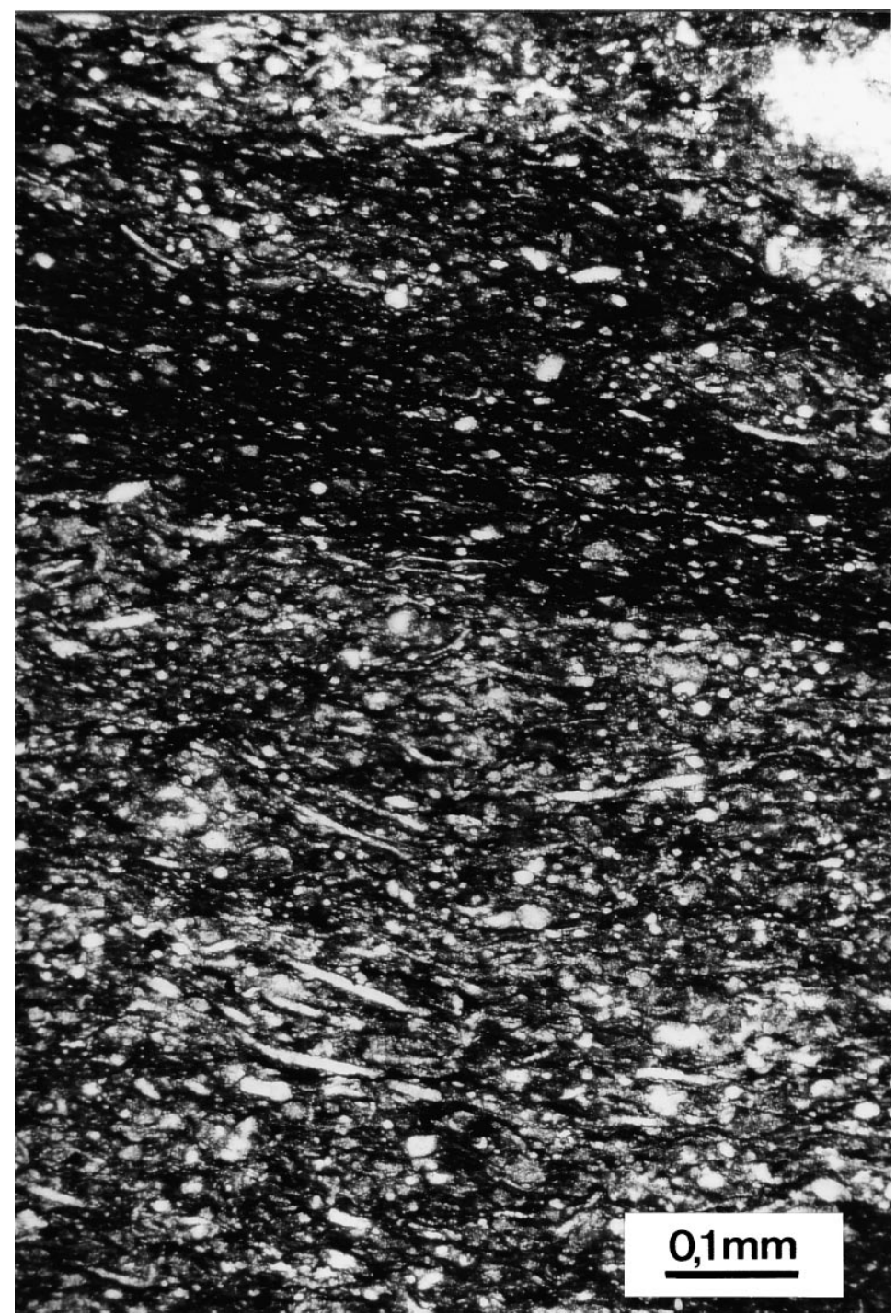

Fig. 4. Spiculitic packstone and wackestone (top) characteristic of the dark, cherty limestone covering the algal mounds. Note the dominant monaxon spicules. 'Spicules' possibly include brachiopod spines. These are abundant in the deep-water Leonardian Bone Springs Limestone in the Guadalupe Mountains (Newell et al., 1953).

stones indicates a rapid rather than gradual sea-level rise. Further criteria against a long-term break are the lack retrogradation of mounds, reworking or erosion at the top of the mounds, and hardgrounds or crusts at the transition of mounds-to-cherty limestones. A rapid sea-level rise is consistent with glacio-eustatic control. The late Paleozoic sea-level rise corresponding to deglaciation intervals was probably rapid and obviously outpaced carbonate growth potential of Anthracoporella.

\section{Geochemical evidence}

Sulfur (S) and total-organic-carbon (TOC) contents of two sections (AI and AR, sites 1 and 5, 
Table 1

Sulfur and TOC contents of the sections AI and AR (1 and 5 of Fig. 1)

\begin{tabular}{|c|c|c|c|c|c|c|}
\hline \multirow[t]{2}{*}{ Sample } & \multicolumn{3}{|l|}{ Sulfur $(\%)$} & \multicolumn{3}{|c|}{ Total organic carbon $(\%)$} \\
\hline & 1st meas. & 2nd meas. & mean & 1st meas. & 2nd meas. & mean \\
\hline AI 4 OM & 0.53 & 0.56 & 0.54 & 0.24 & 0.23 & 0.23 \\
\hline AI 6 OM & 0.72 & 0.69 & 0.70 & 0.33 & 0.38 & 0.35 \\
\hline AI 7 OM & 0.38 & 0.40 & 0.39 & 0.25 & 0.26 & 0.25 \\
\hline AI $10 \mathrm{M}$ & 0.02 & 0.02 & 0.02 & 0.19 & 0.17 & 0.19 \\
\hline AI 11 OM & 0.33 & 0.29 & 0.31 & 0.40 & 0.39 & 0.39 \\
\hline AI 19c M & 0.02 & 0.02 & 0.02 & 0.18 & 0.18 & 0.18 \\
\hline AI 19d M & 0.02 & 0.02 & 0.02 & 0.19 & 0.19 & 0.19 \\
\hline AI $19 \mathrm{e} \mathrm{M}$ & 0.02 & 0.02 & 0.02 & 0.13 & 0.13 & 0.13 \\
\hline $\begin{array}{l}\text { Mean values sect } \\
\text { cherty limestone } \\
\text { mound facies }\end{array}$ & & & $\begin{array}{l}\mathbf{0 . 4 8} \\
0.02\end{array}$ & & & $\begin{array}{l}\mathbf{0 . 3 0} \\
0.17\end{array}$ \\
\hline AR 1a M & 0.03 & 0.03 & 0.03 & 0.10 & 0.12 & 0.11 \\
\hline AR 1b M & 0.02 & 0.02 & 0.02 & 0.09 & 0.09 & 0.09 \\
\hline AR 1c OM & 0.06 & 0.05 & 0.05 & 0.58 & 0.58 & 0.58 \\
\hline AR 2a M & 0.04 & 0.03 & 0.03 & 0.09 & 0.09 & 0.09 \\
\hline AR 2b OM & 0.02 & 0.02 & 0.02 & 0.24 & 0.22 & 0.23 \\
\hline AR 3b M & 0.02 & 0.01 & 0.01 & 0.09 & 0.07 & 0.08 \\
\hline AR 3c OM & 0.05 & 0.05 & 0.05 & 0.56 & 0.57 & 0.56 \\
\hline AR 3d OM & 0.08 & 0.07 & 0.07 & 0.68 & 0.66 & 0.67 \\
\hline AR 3e M & 0.03 & 0.04 & 0.03 & 0.16 & 0.15 & 0.15 \\
\hline $\begin{array}{l}\text { Mean values sect } \\
\text { cherty limestone } \\
\text { mound facies }\end{array}$ & & & $\begin{array}{l}\mathbf{0 . 0 5} \\
0.02\end{array}$ & & & $\begin{array}{l}\mathbf{0 . 5 1} \\
0.10\end{array}$ \\
\hline
\end{tabular}

$\mathrm{M}$ and $\mathrm{OM}$ indicate mound facies and cherty limestone (shroud facies), respectively. S values for mound samples are nearly constant by $0.02 \%$ for both sections. Mean TOC values for the mound facies are 0.17 for section AI and $0.10 \%$ for section AR. S values of cherty limestone are nearly five times higher for section AI $(0.48 \%)$ and two times higher for section AR $(0.05 \%)$. TOC values of samples originated from cherty limestones are significantly higher with $0.30 \%$ for the section AI and $0.51 \%$ for section AR. Although the two sections show minor variation in their respective S contents, differences, particularly in TOC contents, are evident. The standard deviation is $<0.01 \%$ for all measurements

respectively, in Fig. 1) which are composed of four and three cyclothems, respectively, have been measured (Table 1). The $\mathrm{S}$ content of algal limestones ranges from 0.02 to $0.04 \%$, and the TOC values from 0.07 to $0.19 \%$. Most of the $\mathrm{S}$ values of the cherty limestones are an order of magnitude higher than those of the algal limestones. The $\mathrm{S}$ values for the cherty limestone range from 0.29 to $0.72 \%$ for section AI and from 0.02 to $0.08 \%$ for section AR. The TOC values range from 0.22 to $0.68 \%$, five times higher than those of the mounds. These geochemical data support the depositional conditions deduced from the facies and paleontological analyses: welloxygenated conditions prevail during the growth of the algal mounds, whereas the cherty limestones accumulated under less oxygenated conditions. The TOC and S contents are generally too low to indicate truly anoxic environments. Nevertheless, the higher $\mathrm{S}$ and TOC values of the cherty limestones clearly indicate less oxic conditions typical of fine-grained sediments (Mitterer and Cunningham, 1985; Morse and Mackenzie, 1990).

\section{Timing and cause of drowning}

The Lower Pseudoschwagerina Limestone, representing one fusulinid zone (Bosbytauella, ex. Occidentoschwagerina alpina Kahler), is composed of four cyclothems (Homann, 1969; Samankassou, 

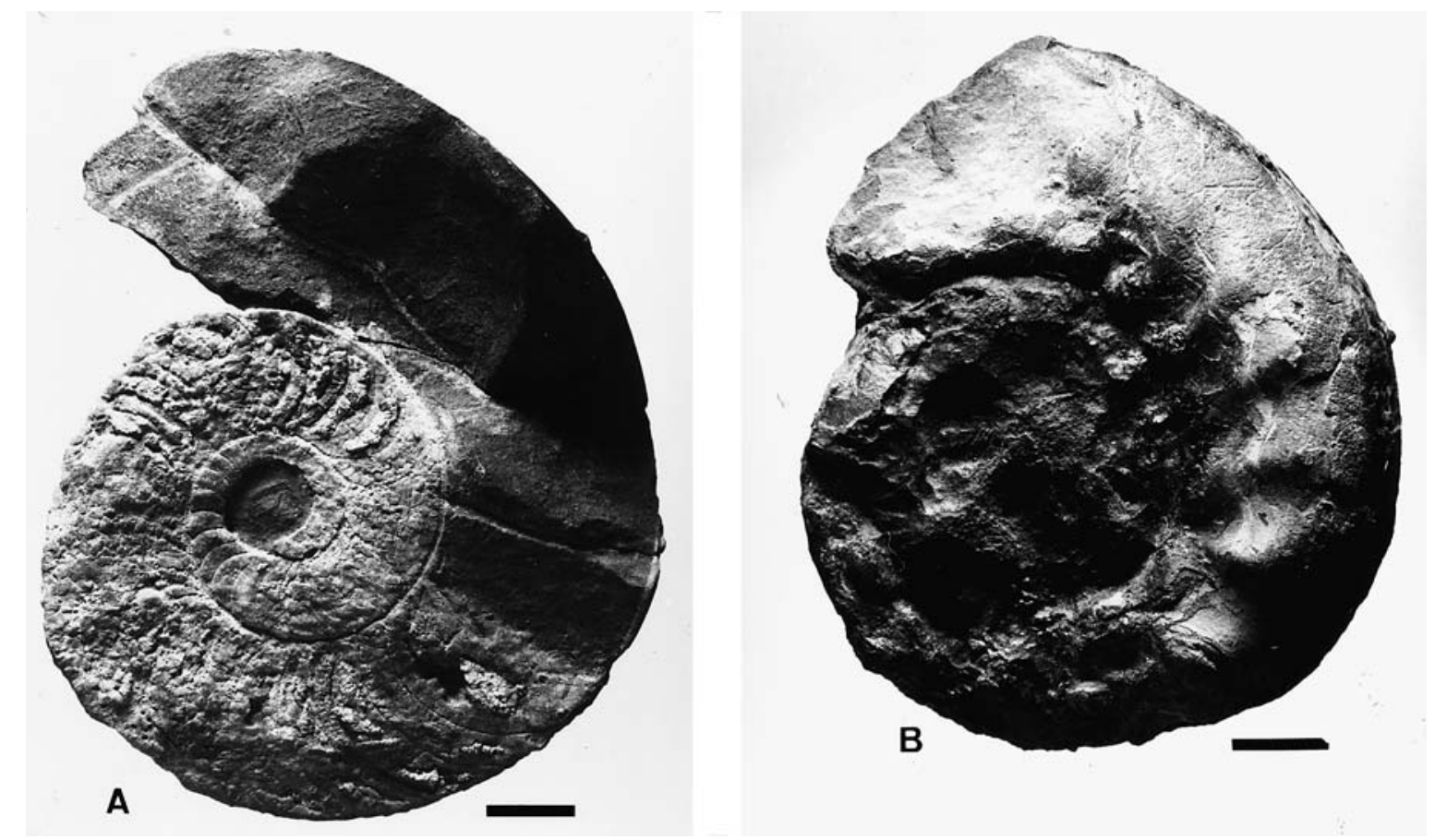

Fig. 5. Nautiloids characteristic of the shroud facies. Most of the found specimens belong to the family Tainoceratidae Hyatt, 1883, probably species of Tainoceras (B.F. Glenister, written commun., 1994). They did not occur within the mound rocks. This obvious biotic change from the mound rock to the overlying cherty limestones reinforces the assumption of a fundamental event. Scale bars $1 \mathrm{~cm}$.

1997a). The mean duration of one fusulinid zone is approximately 1.0 million years (Ross and Ross, 1995), implying a mean duration of 0.25 million years for each single cyclothem. This value is not overestimated, considering a duration estimated for cyclothems from the American Midcontinent: 0.235 to 0.400 million years for major cyclothems (Heckel, 1986, 1994; cf. also Klein, 1994 for discussion). Assuming that cyclothems are time equivalent and that mounds developed during the transgressive limb of a cyclothem (assuming that cyclothems are approximately symmetric with respect to time; Samankassou, 1997a), the drowning interval is shorter than half of one cyclothem, that is $<0.125$ million years. Considering the abrupt transition from mound to the cherty limestone ('shroud facies') (Fig. 6), the actual duration was probably considerably shorter. This interval $(<0.125$ million years $)$ is too short for any event other than those driven by glacio-eustasy (Soreghan, 1994; Dickinson et al., 1994; Heckel, 1994). Furthermore, the repeated (cyclic) patterns are inconsistent with a tectonic cause as a major controlling factor.

\section{Summary and interpretation}

Sedimentological and paleontological data document two environments: (1) the Anthracoporellamound growth occurred between wave base and the base of the photic zone; (2) the algal mounds were drowned by sea-level rise, carbonate production declined below the photic zone, and poorly oxygenated lime mud accumulated. The resulting pattern is characteristic of drowning episodes (Kendall and Schlager, 1981; Schlager, 1981, 1998, 1999; Neumann and Macintyre, 1985): algal mounds overlain by deeper-water limestones. In the initial stages, the relative sea level rose slowly enough that the algae could keep up as accommodation space was created and remain in the photic zone. Later, the rate of sea-level rise became too high and the mound 


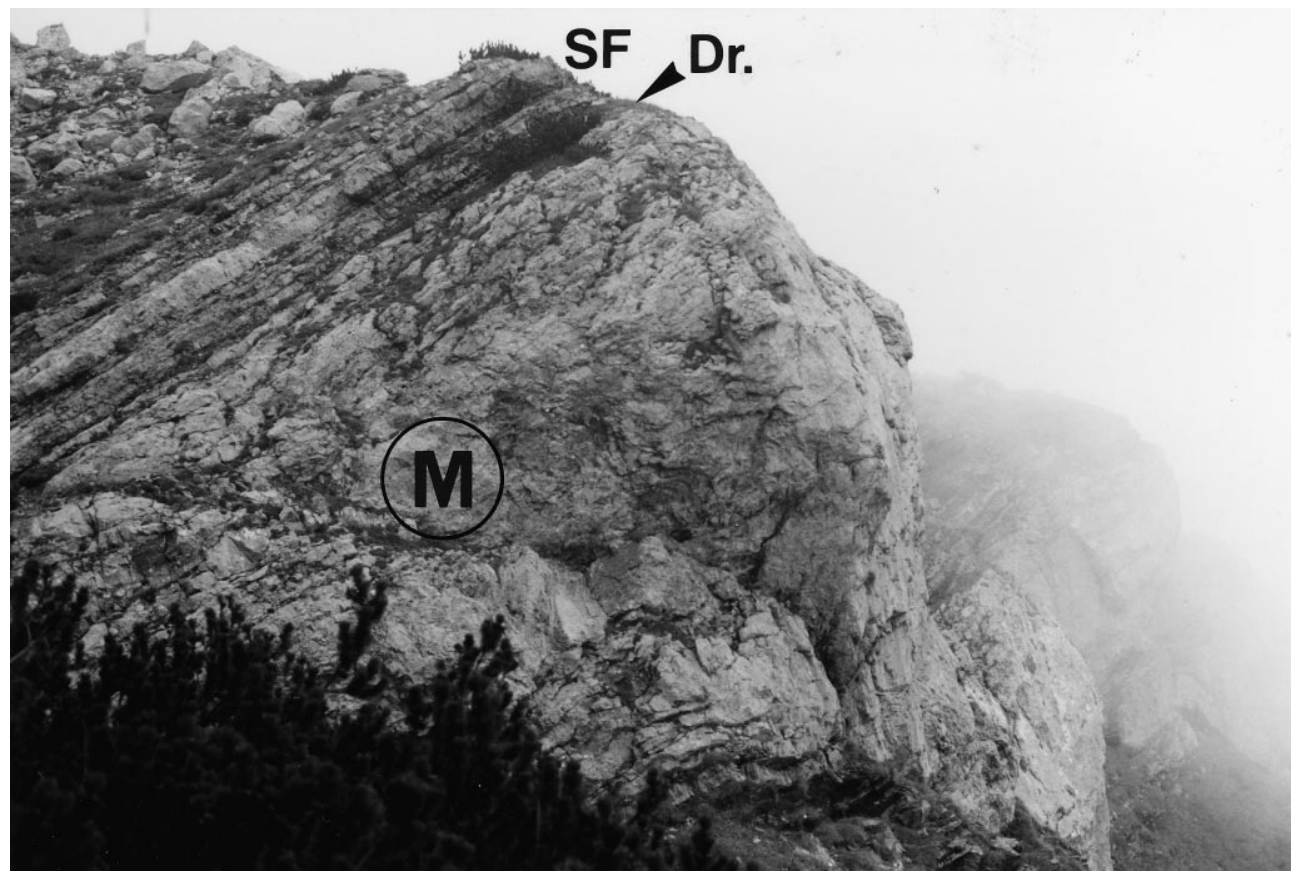

Fig. 6. Picture illustrating the drowning interval ( $D r$. $)$ of mounds: massive algal limestone $(M)$ is overlain by well-bedded cherty limestone (shroud facies, $S F$ ). The cherty limestones lack Anthracoporella and are typical deeper-water deposits. They record the death and burial of Anthracoporella mounds and are therefore termed the shroud facies (cf. model Fig. 7).

crests dropped below the photic zone; mounds and intermounds were drowned (give-up reefs related to Neumann and Macintyre, 1985). The mud-rich sediments covering the mounds result in death and burial of Anthracoporella mounds and are therefore termed the shroud facies (Fig. 7).

The relative sea-level rise was not permanent. Subsequent relative sea-level fall again brought the sea bottom within the photic zone. Drowning and subsequent sea-level fall intervals are recorded in nearly every cyclothem. The only exception is the second cycle, which lacks an obvious shroud facies. This was due to the high paleorelief of the particularly thick mounds in the first cycle (Samankassou, 1997a). The frequent and high-amplitude sea-level rise events recorded fit well with sea-level change caused by late Paleozoic glaciation and deglaciation events on Pangea. This drowning mode differs from most of the drowning events described from other time intervals.

This case study presents a drowning event without prior exposure (Schlager, 1998), at a smaller scale compared to processes on large platforms discussed therein. The shroud facies has been used as marker horizon by previous investigations in the Lower Pseudoschwagerina Limestone. It has been used e.g. by Homann (1969) to correlated cyclothems. This demonstrates how useful the drowning events could be applied in sequence stratigraphic studies, particularly in fully subtidal deposits as the Lower Pseudoschwagerina Limestone (cf. Schlager, 1999, for application of drowning intervals as unique sequence boundaries in particular cases).

\section{Discussion}

Alternative factors that could have caused the reported drowning events are: tectonic subsidence, nutrient supply, climatic changes, biotic turnover, and/or changes in salinity.

Rates of tectonic changes are generally an order of magnitude lower than the documented drowning events (Samankassou, 1997a; cf. also calculations 


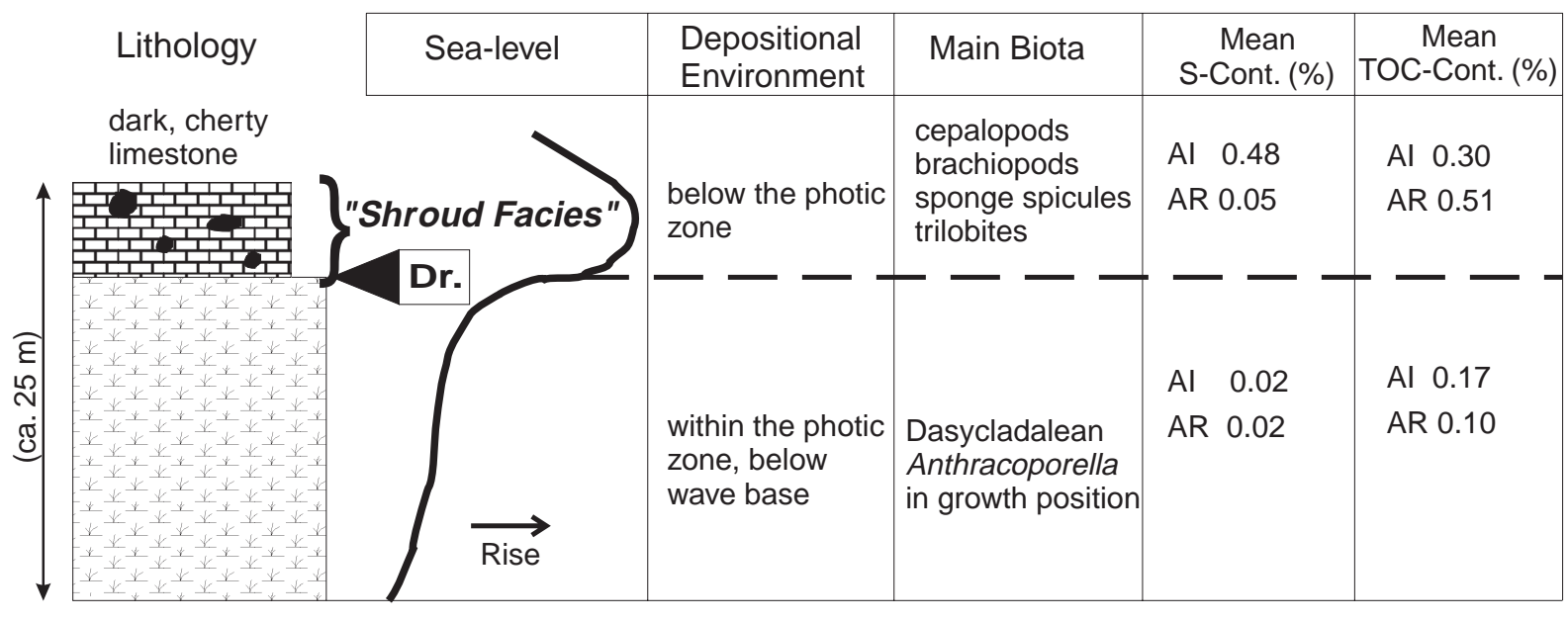

massive limestone

(algal mounds)

Fig. 7. Sequence of mound drowning. Arrow indicates the drowning event. Field relations are illustrated in Fig. 6. Algal limestones can be differentiated from the shroud facies beds sedimentologically (Fig. 5) and petrographically (Fig. 3 vs. Fig. 4), and geochemically (Table 1).

by Heckel, 1994, for magnitude of glacio-eustatic vs. tectonic driven sea-level changes for the American Midcontinent cyclothems, as well as Maynard and Leeder, 1992). Furthermore, no high-frequency cyclic tectonic events have ever been reported (cf. Soreghan, 1994; Heckel, 1994). Tectonic events, probably the main factor controlling the drowning of Triassic platforms among others (Bosellini, 1989), did not play a significant role in the Lower Pseudoschwagerina Limestone.

Nutrient supply is an important factor in drowning intervals (Hallock and Schlager, 1986). An excess of nutrients would be documented as a shift in biotic composition, from an autotrophic community to a heterotrophic association (e.g. bryozoans, crinoids) in the post-drowning rocks (Wood, 1993; Martin, 1996). This is not the case in the cherty limestone described herein. A nutrient-driven drowning can therefore be ruled out from the possible factors causing the mound drowning.

Climatic change is an important factor in upper Paleozoic cyclic sediments (West et al., 1997 and other references therein). A drowning interval caused principally by climatic fluctuations should be mirrored in differences, among others, in sediment supply and mineralogy. There are no major variations in terrigenous material contents between mound rocks and the overlying cherty limestones (Homann, 1969). This does not support a climatic change controlling drowning in the present case study.

Further evidence of climatic change or variation in salinity is also lacking. A cooling causing demise of green algae is not realistic because of the paucity of cool-water biota within the shroud facies. Changes in salinity may affect carbonate production and lead to drowning, as demonstrated off the southeast coast of Florida (cf. Neumann and Macintyre, 1985). Both mound rocks and shroud facies are characterized by a normal-marine biota. The lithological change is not linked with a salinity shift, whether increasing or decreasing. The biotic composition excludes salinity as a cause for the drowning.

Other factors may be associated in part with sea-level rise. A glacio-eustatic sea-level rise is caused by melting processes and linked with climatic changes, changes in oceanographic circulations, oxygenic conditions, and/or nutrient regimes (R. Henrich and A. Strasser, pers. commun., 1998). But neither one, nor a combination of these factors, if not linked with very rapid and high-frequency sealevel rise characteristic of glacio-eustasy, could lead to the documented drowning. 


\section{Conclusions}

Dasycladalean reef mounds occurring within the Lower Pseudoschwagerina Limestone cyclothems are overlain by deeper-water limestone. Sedimentological, paleontological and geochemical data document drowning events.

(1) Light-colored, massive limestones accumulated within the photic zone and are directly overlain by dark, cherty limestones, deposited below the photic zone. This reflects a rapid sea-level rise that drowned the algal mounds.

(2) Mounds are composed of the dasycladalean alga Anthracoporella. The overlying cherty limestone includes a typical deeper-water biota of cephalopods, spinose brachiopods, and sponge spicules; it lacks Anthracoporella in growth position.

(3) Paleontological and geochemical data are supported by geochemical results. The $\mathrm{S}$ contents of the light-colored algal limestones range from 0.02 to $0.04 \%$. The values for the cherty limestones are an order of magnitude higher at $0.02-0.76 \%$ (mean values 0.05 and $0.48 \%$, respectively, for sections AR and $\mathrm{AI})$. The TOC values show comparable patterns: $0.07-0.19 \%$ in the mound limestone compared to $0.23-0.68 \%$ in the overlying cherty limestones. The cherty limestones accumulated under less oxygenated conditions. They mark the termination of the mounds and the demise of the mound-building algae.

(4) Environmental factors like climate, nutrient excess and salinity shifts do not represent an alternative to glacio-eustasy that is interpreted as the main cause of drowning. In addition, repeated patterns within this short time interval exclude a tectonic cause for the documented drowning.

\section{Acknowledgements}

I acknowledge the 'Pangea Working Group' in Erlangen (E. Flügel, B. Fohrer, H. Forke) for diverse and enduring support, M.L. Neufert and Ch. Sporn (Erlangen) for microphotographs, and the KFA Jülich (particularly B. Horsfield and D. Bruss) for facilities for geochemical measurements. Paul Enos (Kansas) provided helpful improvements to an earlier draft of the paper. Journal reviewers Jeroen
Kenter, Brenda Kirkland-George, and Bruce Sellwood improved the final manuscript. Financial support of the Deutsche Forschungsgemeinschaft (Fl $42 / 72$ to E. Flügel) is acknowledged.

\section{References}

Beauchamp, B., Harrison, J.C., Henderson, C.M., 1989. Upper Paleozoic stratigraphy and basin analysis of the Sverdrup Basin, Canadian Arctic Archipelago, 2. Transgressiveregressive sequences. Current Research, Part G, Geological Survey of Canada, Paper 89-1G, pp. 115-124.

Bernoulli, D., Jenkyns, H.C., 1974. Alpine, Mediterranean, and central Atlantic Mesozoic facies in relation to the early evolution of the Tethys. In: Dott, R.H., Jr., Shaver, R.H. (Eds.), Modern and Ancient Geosynclinal Sedimentation. Soc. Econ. Paleontol. Mineral. Spec. Publ. 19, 129-160.

Bice, D.M., Stewart, K.G., 1990. The formation and drowning of isolated carbonate seamounts: tectonic and ecological controls in the northern Apennines. In: Tucker, M.E., Wilson, J.L., Crevello, P.D., Sarg, J.R., Read, J.F. (Eds.), Carbonate Platforms: Facies, Sequences and Evolution. Int. Assoc. Sedimentol. Spec. Publ. 9, 145-168.

Blanchon, P., Shaw, J., 1995. Reef drowning during the last deglaciation: evidence for catastrophic sea-level rise and icesheet collapse. Geology 23, 4-8.

Bosellini, A., 1989. Dynamics of Tethyan carbonate platforms. In: Crevello, P.D., Wilson, J.L., Sarg, J.F., Read, J.F. (Eds.), Controls on Carbonate Platform and Basin Development. Soc. Econ. Paleontol. Mineral. Spec. Publ. 44, 3-14.

Camoin, G.F., Arnaud Vanneau, A., Bergersen, D.D., Colonna, M., Ebren, P., Enos, P., Ogg, J.G., 1995. Anatomy and evolution of the inner perimeter ridge (Sites 874 and 877) of a Campanian-Maastrichtian atoll-like structure (Wodejebato Guyot, Marshall Islands). Proc. ODP, Sci. Results 144, 271294.

Chafetz, H.S., 1986. Marine peloids: a product of bacterially induced precipitation of calcite. J. Sediment. Petrol. 56, 812817.

Dickinson, W.R., Soreghan, G.S., Giles, K.A., 1994. Glacio-eustatic origin of Permo-Carboniferous stratigraphic cycles: evidence from the southern Cordilleran foreland region. In: Dennison, J.M., Ettensohn, F.R. (Eds.), Tectonic and Eustatic Controls on Sedimentary Cycles. Soc. Econ. Paleontol. Mineral., Concepts in Sedimentology and Paleontology, 4, 25-34.

Dominguez, L.L., Mullins, H.T., Hine, A.C., 1988. Cat Island platform, Bahamas: an incipiently drowned Holocene carbonate. Sedimentology 35, 805-820.

Enos, P., Camoin, G.F., Ebren, P., 1995. Sedimentary sequence from Sites 875 and 876, outer perimeter ridge, Wodejebato Guyot. Proc. ODP, Sci. Results 144, 295-310.

Enos, P., Jiayong, W., Lehrmann, D.J., 1998. Death in Guizhou - Late Triassic drowning of the Yangtze Platform. Sediment. Geol. 118, 55-76. 
Erlich, R.N., Barrett, S.F., Ju, G.B., 1990. Seismic and geologic characteristics of drowning events on carbonate platforms. Am. Assoc. Pet. Geol. Bull. 74, 1523-1537.

Flügel, E., 1980. Die Mikrofazies der Kalke in den TrogkofelSchichten der Karnischen Alpen. Carinthia II, Sonderh. 36, $51-100$.

Flügel, E., 1981. Lower Permian Tubiphytes/Archaeolithoporella buildups in the southern Alps (Austria and Italy). In: Toomey, D.F. (Ed.), European Fossil Reef Models. Soc. Econ. Paleontol. Mineral. Spec. Publ. 30, 143-160.

Grötsch, J., Flügel, E., 1992. Facies of sunken Early Cretaceous atoll reefs and their capping Late Albian drowning succession (Northern-Pacific). Facies 27, 153-174.

Guo, L., Riding, R., 1992. Microbial carbonates in uppermost Permian reefs, Sichuan basin, southern China: some similarities with Recent travertines. Sedimentology 39, 37-53.

Hallock, P., Schlager, W., 1986. Nutrient excess and the demise of coral reefs and carbonate platforms. Palaios 1, 389-398.

Heckel, P.H., 1986. Sea-level curve for Pennsylvanian eustatic marine transgressive-regressive depositional cycles along midcontinent outcrop belt, North America. Geology 14, 330-334.

Heckel, P.H., 1994. Evaluation of evidence for glacio-eustatic control over marine Pennsylvanian cyclothems in North America and consideration of possible tectonic effects. In: Dennison, J.M., Ettensohn, F.R. (Eds.), Tectonic and Eustatic Controls on Sedimentary Cycles. Soc. Econ. Paleontol. Mineral., Concepts in Sedimentology and Paleontology, 4, 65-87.

Homann, W., 1969. Fazielle Gliederung der Unteren Pseudoschwagerinenkalke (Unter-Perm) der Karnischen Alpen. Neues Jahrb. Geol. Paläontol., Monatsh. 1969, 265-280.

Hurst, J.M., Sheehan, P.M., Pandolfi, J.M., 1985. Silurian carbonate shelf and slope evolution in Nevada: a history of faulting, drowning, and progradation. Geology 13, 185-188.

Kahler, F., 1955. Entwicklungsräume und Wanderwege der Fusulinen im Euroasiatischen Kontinent. Geologie 4, 179-188.

Kendall, C.G.St.C., Schlager, W., 1981. Carbonates and relative changes in sea level. Mar. Geol. 44, 181-212.

Klein, G.D., 1994. Depth determination and quantitative distinction of the influence of tectonic subsidence and climate on changing sea level during deposition of Midcontinent Pennsylvanian cyclothems. In: Dennison, J.M., Ettensohn, F.R. (Eds.), Tectonic and Eustatic Controls on Sedimentary Cycles. Soc. Econ. Paleontol. Mineral., Concepts in Sedimentology and Paleontology, 4, 45-50.

Kraft, W., 1993. Sedimentär induzierte Zyklen im Unterperm der Karnischen Alpen. Unpubl. Diploma Thesis, Universität Erlangen-Nürnberg, Erlangen, 100 pp.

Krainer, K., 1992. Fazies, Sedimentationsprozesse und Paläogeographie im Karbon der Ost- und Südalpen. Jahrb. Geol. Bundesanst. 135, 99-193.

Lavoie, D., 1992. The Middle Ordovician (Caradocian) Deschambault Formation, St. Lawrence Lowlands, southern Quebec: a shallow water carbonate ramp on a drowning platform. Current Research, Part D, Geological Survey of Canada, Paper 92-1D, pp. 223-234.

Macintyre, I.G., 1985. Submarine cements C the peloidal question. In: Schneidermann, N., Harris, P.M. (Eds.), Carbonate
Cements. Soc. Econ. Paleontol. Mineral. Spec. Publ. 36, 109116.

Marshall, J.F., 1983. Submarine cementation in a high-energy platform reef: One Tree Reef, southern Great Barrier Reef. J. Sediment. Petrol. 53, 1133-1149.

Martin, R.E., 1996. Secular increase in nutrient levels through the Phanerozoic: Implications for productivity, biomass, and diversity in the marine biosphere. Palaios 11, 209-219.

Matthews, J.L., Heezen, B.C., Catalano, C., Coogan, A., Tharp, M., Natland, J., Rawson, M., 1974. Cretaceous drowning of reefs on Mid-Pacific and Japanese Guyots. Science 184, 462464.

Maynard, J.R., Leeder, M.R., 1992. On the periodicity and magnitude of Late Carboniferous glacio-eustatic sea-level changes. J. Geol. Soc. London 149, 303-311.

Meyer, F.O., 1989. Siliciclastic influence on Mesozoic platform development: Baltimore Canyon Trough, Western Atlantic. In: Crevello, P.D., Wilson, J.L., Sarg, J.F., Read, J.F. (Eds.), Controls on Carbonate Platform and Basin Development. Soc. Econ. Paleontol. Mineral. Spec. Publ. 44, 213-232.

Mitterer, R.M., Cunningham, R., Jr., 1985. The interaction of natural organic matter with grain surfaces: implications for calcium carbonate precipitation. In: Schneidermann, N., Harris, P.M. (Eds.), Carbonate Cements. Soc. Econ. Paleontol. Mineral. Spec. Publ. 36, 17-31.

Morse, J.W., Mackenzie, F.T., 1990. Geochemistry of Sedimentary Carbonates. Elsevier, Amsterdam, 696 pp.

Neumann, A.C., Macintyre, I., 1985. Reef response to sea level rise: keep-up, catch-up or give-up. Proc. Fifth Int. Coral Reef Congr., Tahiti, 3, 105-110.

Newell, N.D., Rigby, J.K., Fischer, A.G., Whiteman, A.J., Hickox, J.E., Bradley, J.S., 1953. The Permian Reef Complex of the Guadalupe Mountains Region, Texas and New Mexico. Freeman, San Francisco, CA, 236 pp.

Poty, E., 1980. Evolution and drowning of paleokarst in Frasnian carbonates at Vis, Belgium. Meded. Rijks Geol. Dienst, 32, 53-55.

Reid, R.P., 1987. Nonskeletal peloidal precipitates in Upper Triassic reefs, Yukon Territory (Canada). J. Sediment. Petrol. 57, 893-900.

Ross, C.A., Ross, J.R.P., 1995. Foraminiferal zonation of the late Paleozoic depositional sequences. Mar. Micropaleontol. 26, 469-478.

Samankassou, E., 1997a. Muster und Kontrollfaktoren der zyklischen Sedimentation im Jungpaläozoikum (OberkarbonUnterperm) der Karnischen Alpen, Österreich: eine integrierte Untersuchung. Ph.D. Thesis, University of Erlangen-Nürnberg, Erlangen, $397 \mathrm{pp}$.

Samankassou, E., 1997b. Palaeontological response to sea-level change: distribution of fauna and flora in cyclothems from the Lower Pseudoschwagerina Limestone (Latest Carboniferous, Carnic Alps, Austria). Geobios 30, 785-796.

Samankassou, E., 1998. Skeletal framework mounds of dasycladalean alga Anthracoporella, Upper Paleozoic, Carnic Alps, Austria. Palaios 13, 297-300.

Santantonio, M., 1994. Pelagic carbonate platforms in the geo- 
logic record: their classification, and sedimentary and paleotectonic evolution. Am. Assoc. Pet. Geol. Bull. 78, 122-141.

Schlager, W., 1981. The paradox of drowned reefs and carbonate platforms. Geol. Soc. Am. Bull. 92, 197-211.

Schlager, W., 1989. Drowning unconformities on carbonate platforms. In: Crevello, P.D., Wilson, J.L., Sarg, J.F., Read, J.F. (Eds.), Controls on Carbonate Platform and Basin Development. Soc. Econ. Paleontol. Mineral. Spec. Publ. 44, 15-26.

Schlager, W., 1998. Exposure, drowning and sequence boundaries on carbonate platforms. In: Camoin, G.F., Davies, P.J. (Eds.), Reefs and Carbonate Platforms in the Pacific and Indian Oceans. Int. Assoc. Sedimentol. Spec. Publ. 25, 3-21.

Schlager, W., 1999. Type-3 sequence boundaries. In: Harris, P.M. (Ed.), Advances in Carbonate Sequence Stratigraphy Application to Reservoirs, Outcrops, and Models. Soc. Econ. Paleontol. Mineral. Spec. Publ. (in press).

Schlager, W., Camber, O., 1986. Submarine slope angles, drowning unconformities, and self-erosion of limestone escarpments. Geology 14, 762-765.

Simo, T., Scott, R.W., Masse, J.P. (Eds.), 1993. Cretaceous carbonate platforms. Am. Assoc. Pet. Geol. Mem. 56, 479 pp.

Soreghan, G.S., 1994. Stratigraphic responses to geologic processes: Late Pennsylvanian eustasy and tectonics in the Pe- dregosa and Orogrande basins, Ancestral Rocky Mountains. Geol. Soc. Am. Bull. 106, 1195-1211.

Steinhauff, D.M., Walker, K.R., 1995. Recognizing exposure, drowning, and 'missed beats': Platform-interior to platformmargin sequence stratigraphy of Middle Ordovician limestones, east Tennessee. J. Sediment. Res. Sect. B, Stratigraphy and Global Studies 65, 183-207.

Szulczewski, M., Belka, Z., Skompski, S., 1996. The drowning of a carbonate platform: An example from the DevonianCarboniferous of the southwestern Holy Cross Mountains, Poland. Sediment. Geol. 106, 21-49.

Venturini, C., 1990. Field workshop on Carboniferous to Permian sequence of the Pramollo-Nassfeld Basin (Carnic Alps) (September 2-8, 1990), Guidebook. Udine, 159 pp.

West, R.R., Archer, A.W., Miller, K.B., 1997. The role of climate in stratigraphic patterns exhibited by late Paleozoic rocks exposed in Kansas. Palaeogeogr., Palaeoclimatol., Palaeoecol. $128,1-16$.

Wilson, P.A., Jenkyns, H.C., Elderfield, H., Larson, R.L., 1998. The paradox of drowned carbonate platforms and the origin of Cretaceous Pacific guyots. Nature 392, 889-894.

Wood, R., 1993. Nutrients, predation and the history of reefbuilding. Palaios $8,526-543$. 